\title{
Gastric siderosis as a cause of dyspepsia
}

\author{
Artur Gião Antunes, ${ }^{1}$ Jesus Cadillá, ${ }^{2}$ Horácio Guerreiro ${ }^{1}$
}

${ }^{1}$ Gastroenterology Department, Centro Hospitalar do Algarve, Faro, Portugal

2Pathology Department, Centro Hospitalar do Algarve, Faro, Portugal

\section{Correspondence to} Dr Artur Gião Antunes, sergiogiao@hotmail.com

Accepted 27 July 2016

\section{DESCRIPTION}

A 66-year-old man was referred to our clinic due to a new onset of postprandial fullness and early satiety. He had a relevant personal history of myelodysplastic syndrome with lifelong regular blood transfusions resulting in a transfusional haemosiderosis (heart failure, pulmonary haemosiderosis, cirrhosis and diabetes). Effective prevention of iron overload was previously unsuccessful due to: allergic reactions with anaphylaxis to oral and intravenous forms of the treatment precluded iron chelation therapy; allergy desensitisation procedures carried out were also fruitless; phlebotomies were contraindicated due to the degree of heart failure. At our evaluation the patient was on chemotherapy with 5 -azacytidine.

We decided for empirical treatment with a proton-pump inhibitor, with no improvement after 4 weeks. An upper endoscopy was performed, which revealed small oesophageal varices, mild portal hypertensive gastropathy with thickened folds and multiple speckled areas of brown pigmentation in the gastric body (figure 1).

Histological examination (figure 2) on $\mathrm{H} \& \mathrm{E}$ stain showed superficial mucosal oedema, chronic inflammation and a brownish pigment in the epithelium, lamina propria and in the glandular lumens. Prussian blue staining was positive for iron

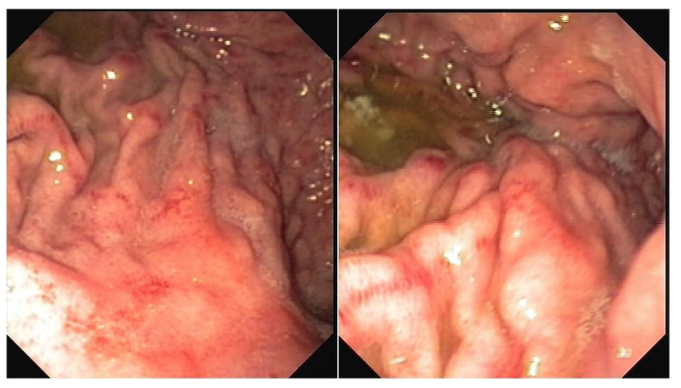

Figure 1 Upper endoscopy showing mucosal congestion, thickened folds and areas of brownish coloration. deposits. There was no evidence of Helicobacter pylori infection. The diagnosis of gastric siderosis was established. Although the differential diagnosis of dyspepsia in this patient was challenging and vast, gastric siderosis was considered one of the possible aetiologies.

Given the presence of important comorbidities as a result of systemic and local iron overload, the patient had a poor prognosis and died soon afterwards.

\section{Learning points}

Haemosiderosis is a form of iron overload disorder. Excess iron is initially deposited in the liver as haemosiderin, and later in other organs like the pancreas and heart, leading to cell damage and organ disease. The stomach has no known role in iron metabolism; therefore, in the absence of oral iron supplements (our case) the identification of increased iron deposition in gastric mucosa (gastric siderosis) is quite rare. ${ }^{1-3}$

- The study of dyspepsia in a patient with haemosiderosis is quite challenging, since we have to consider some specific aetiologies, namely gastroparesis secondary to diabetes, dyspepsia related to congestive heart failure or even as the consequence of local inflammation secondary to iron deposition. ${ }^{1-3}$

- Given its rarity, the pathophysiology, clinical implications and treatment of gastric siderosis are not well defined. Most authors recommend that the treatment should focus on the management of the main cause of iron metabolism imbalance and iron chelation therapy. The literature lacks information concerning the changes of gastric haemosiderin deposits when iron chelation therapy is used. ${ }^{1-3}$
To cite: Antunes $A G$, Cadillá J, Guerreiro H. BMJ Case Rep Published online: [please include Day Month Year] doi:10.1136/bcr-2016216862

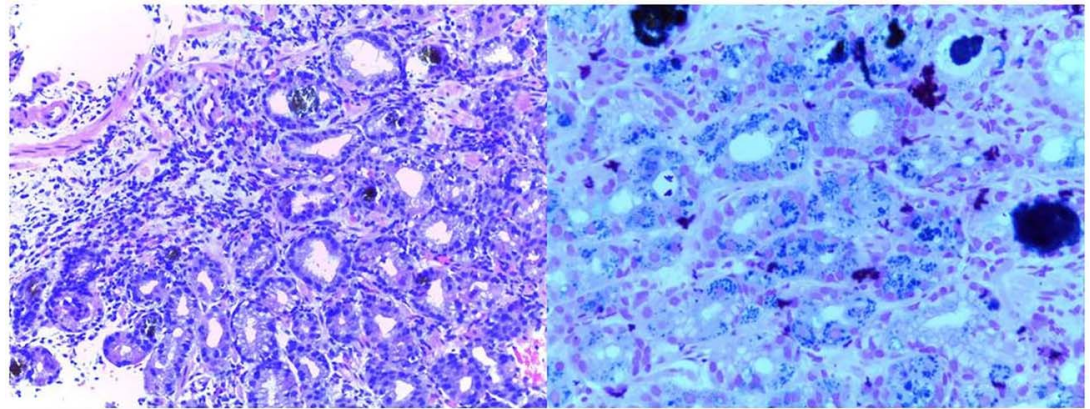

Figure 2 H\&E and Prussian blue iron stain of gastric mucosa showing iron deposition. 
Contributors AGA was responsible for the majority of the writing, including the scientific review. JC was responsible for histological description and writing. HG was responsible for major corrections of the manuscript. All authors have participated in the conception and design of the work that has resulted in the article in question.

Competing interests None declared.

Patient consent Obtained.

Provenance and peer review Not commissioned; externally peer reviewed.

\section{REFERENCES}

1 Kothadia JP, Arju R, Kaminski M, et al. Gastric siderosis: an under-recognized and rare clinical entity. SAGE Open Med 2016;4:2050312116632109.

2 Marginean EC, Bennick M, Cyczk J, et al. Gastric siderosis: patterns and significance. Am I Surg Pathol 2006;30:514-20.

3 Levy A, Bongiorno C, Myint MA, et al. The endoscopic appearance of focal gastric hemosiderosis as a brown macular patch resembling that of cutaneous iron deposition in hemochromatosis. Am J Gastroenterol 2008;103:246-8.

Copyright 2016 BMJ Publishing Group. All rights reserved. For permission to reuse any of this content visit

http://group.bmj.com/group/rights-licensing/permissions.

BMJ Case Report Fellows may re-use this article for personal use and teaching without any further permission.

Become a Fellow of BMJ Case Reports today and you can:

- Submit as many cases as you like

- Enjoy fast sympathetic peer review and rapid publication of accepted articles

- Access all the published articles

- Re-use any of the published material for personal use and teaching without further permission

For information on Institutional Fellowships contact consortiasales@bmjgroup.com

Visit casereports.bmj.com for more articles like this and to become a Fellow 